\title{
Status of Animal Husbandry in Maharashtra
}

\section{S K Das*}

Principal Scientist, Training and Education Centre (TEC), ICAR - Indian Veterinary Research Institute (IVRI), Shivajinagar, Pune, Maharashtra, India

*Corresponding Author: S K Das, Principal Scientist, Training and Education Centre (TEC), ICAR - Indian Veterinary Research Institute (IVRI), Shivajinagar, Pune, Maharashtra, India.
Received: October 26, 2021

Published: December 08, 2021

(C) All rights are reserved by $\mathbf{S} \mathbf{K}$ Das.

\begin{abstract}
Maharashtra is rich source of livestock germplasam particularly in cattle, buffalo and goat. So, due care is needed for veterinary services to keep the animals healthy and productive. So, the state animal husbandry departments should ensure availability of most of the important medicines and vaccine to the livestock owners to enhance production of livestock and to reduce morbidity and mortality of animal. In this review article population dynamics of different species of livestock, breeds of different species available in the state of Maharashtra and their production, existing housing, feeding and health management system, different constraints for the development of livestock sector in Maharashtra and strategies to overcome the bottlenecks were described and highlighted.
\end{abstract}

Keywords: Animal Husbandry; Livestock; Maharashtra

Population dynamics of different species of animal in Maharashtra

- Livestock especially cattle are a traditional component of livestock production systems of Maharashtra. As per $20^{\text {th }}$ Livestock Census (2019) [1] the bovine livestock population of Maharashtra is 19.50 million out of which cattle population is 13.90 million (7.22\% of national population of 192.5 million) and buffaloes population is 5.60 million (5.10\% of national population of 109.9 million). Maharashtra in cattle population stands fifth position next to West Bengal, Uttar Pradesh, Madhya Pradesh and Bihar whereas it stands seventh position in buffalo population next to Uttar Pradesh, Rajasthan, Gujarat, Madhya Pradesh, Bihar and Andhra Pradesh. There is a decline of $10.07 \%$ cattle population but $0.17 \%$ increase of buffalo population in this census over $19^{\text {th }}$ livestock census of 2012.

- $\quad$ As per $20^{\text {th }}$ Livestock Census (2019), in Maharashtra goat population is 10.60 million (7.11\% of National popula- tion of 148.88 million). Sheep population in Maharashtra is 2.70 million (3.64\% of National population of 74.26 million). Maharashtra ranks sixth position in goat population next to Rajasthan, West Bengal, Uttar Pradesh, Bihar and Madhya Pradesh whereas it ranks seventh position in sheep population next to Telangana, Andhra Pradesh, Karnataka, Rajasthan, Tamil Nadu, Jammu and Kashmir. There is a rise of $25.72 \%$ goat population and rise of $3.87 \%$ sheep population in this census over the $19^{\text {th }}$ livestock census of 2012 .

- $\quad$ Poultry population in Maharashtra as per $20^{\text {th }}$ Livestock Census (2019), is 74.30 million (8.72\% of National population of 851.81 million). In poultry population Maharashtra ranks fifth position next to Tamil Nadu, Andhra Pradesh, Telangana and West Bengal. There is a decline of $4.49 \%$ poultry population in this census over the $19^{\text {th }}$ livestock census of 2012.

- $\quad$ Population of horses and ponies in Maharashtra as par latest census 2019 was 0.19 lakh which was $49.33 \%$ decline over the last census of 2012. 
- Milk production in Maharashtra is $\mathbf{1 1 . 6 6}$ million ton during 2018-19 and ranks seventh in India $16.21 \%$ of total milk yield of 187.75 million ton in India) next to UP (30.52m), Rajasthan (23.67m), MP (15.91m), AP (15.04m), Gujarat (14.49m) and Punjab (12.60m) as per statistics of Department of Animal Husbandry and Dairying, GOI, 2019.

- Meat production in Maharashtra is 1.02 million ton during 2018-19 and ranks second in India (12.58\% of total meat yield of 8.11 million ton in India) next to UP (1.23 million ton) as per statistics of Department of Animal Husbandry and Dairying, GOI, 2019.

- $\quad$ Egg production in Maharashtra is 59649 lakh number during 2018-19 and ranks seventh in India $5.77 \%$ of total egg production of 1033176 lakh number in India) next to AP (197545 lakh number), TN (188422 lakh number), Telangana (136868 lakh number), WB (85999 lakh number), Haryana (60577 lakh number) and Karnataka (59994 lakh number) as per statistics of Department of Animal Husbandry and Dairying, GOI, 2019.

- Wool production in Maharashtra is 1385.78 thousand kg during 2017-18 and ranks ninth next to Rajasthan (14463.36 thousand Kg), Karnataka, (8821.44 thousand Kg), Jammu and Kashmir (8371.01 thousand Kg), Telangana (4422.97 thousand Kg), Gujarat (2577.41 thousand Kg), Himachal Pradesh (1663.07 thousand Kg), Uttar Pradesh (1493.71 thousand Kg) and Haryana (1428.69 thousand $\mathrm{Kg}$ ) as per statistics of Department of Animal Husbandry and Dairying, GOI, 2019.

Different breeds of animal originated and distributed in Maharashtra

Cattle

Most predominant cattle breeds reared in Maharashtra are Deoni, Khillari, Red Kandahari, Dangi and Gaolao.

The name of the breed "Deoni" is derived from the Deoni taluka of Latur district of Maharashtra. Home tract is Maharashtra and Karnataka. It is dual purpose breed. The breed is for milk and draught purpose. Population is 73000 as per ICAR - NBAGR (2000). Cows of this breed are moderately good milkers, lactation yield is $1200 \mathrm{~kg}$ in a lactation period of 300 days. Deoni bullocks are good for heavy work and are particularly suitable for intensive cultivation. Available at State Farm (GOM), Udgir, Maharashtra; Marathwada Agril University, Parabani, Maharashtra; UAS, Dharwad, Karnataka.

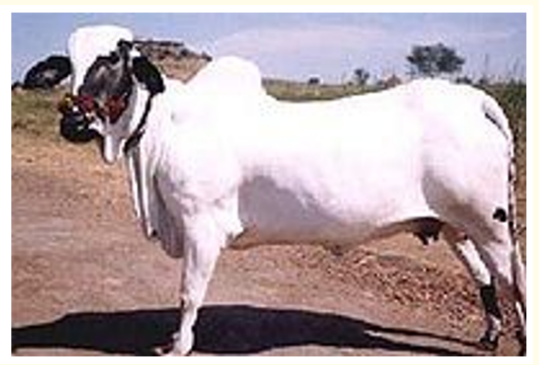

Figure 1

The Khilari cattle breed is native to Satara, Kolhapur and Sangli districts in Maharashtra and Bijapur, Dharwad and Belgaum districts of Karnataka. The breed is well adapted to the tropical and drought prone conditions present in the region. The breed is for draught and milk purpose. Population is 9,67,000 as per ICAR NBAGR (2000). This is basically draught breed, but lactation milk yield is $450 \mathrm{~kg}$ in a lactation period of 225 days. This breed is available at State Farm (GOM): Hingoli, Jath, Junoni, Maharashtra; State Farm (GOK), Bankapur, Karnataka.

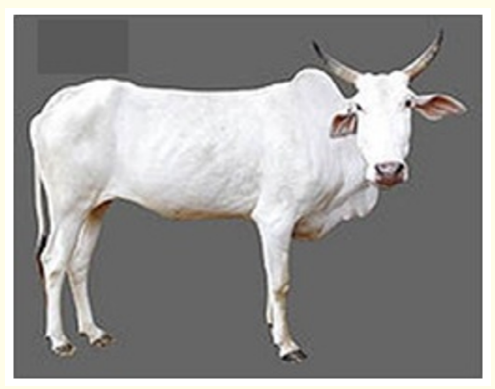

Figure 2

The Dangi cattle breed is originated in the hilly tracts of Nasik and Ahmednagar districts in the state of Maharashtra. Home tract is Maharashtra and MP. The breed is medium to large in body size. 
Population is 90,000 as per ICAR - NBAGR (2000). The breed is white coloured with black spots. Lactation milk yield is $430 \mathrm{~kg}$ in a lactation period of 270 days. Cows are poor milker, bullocks are suitable for ploughing in heavy rainfall area of Konkan region.

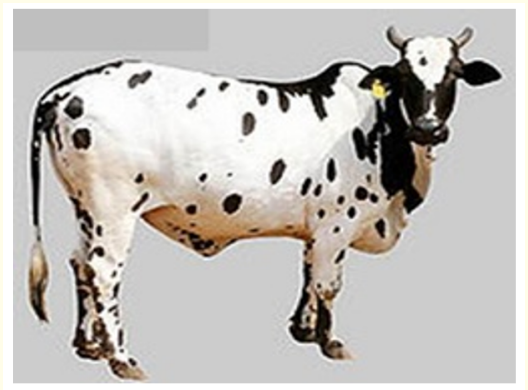

Figure 3

Red Kandhari cattle breed is known to have originated in Kandhar taluk in Nanded district, Latur and Parabani district of Maharashtra. They are also found in Hingoli and Beed district of Maharashtra. Population is $1,76,000$ as per ICAR - NBAGR (2000). This is basically draught breed. Cows are low milk producers and bullocks of the breed are preferred over the Deoni breed for better draught ability and smaller size. Lactation milk yield is $600 \mathrm{~kg}$ in a lactation period of 260 days.

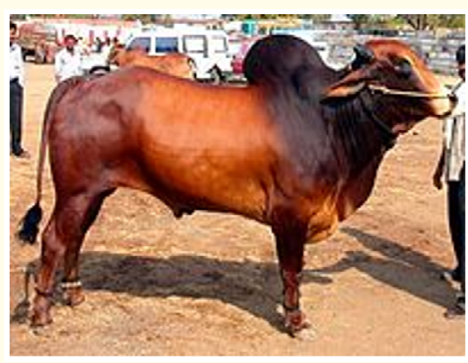

Figure 4

Gaolao cattle breed is a dual purpose cattle breed used both as draught and milk cattle. It originated in the region consisting of Wardha district in Maharashtra, Balaghat and Chindwada districts in Madhya Pradesh and Rajnandgaon district in Chattisgarh state. Population is 36,000 as per ICAR - NBAGR (2000). The cattle are large and well built in size, and usually are of white to gray complexions. Lactation milk yield $600 \mathrm{~kg}$ in a lactation period of 240 days. This breed is available at Central Breeding Institute, Hetikundi; State Farm (GOM), Hetikundi, Pohara, Yeotmal.

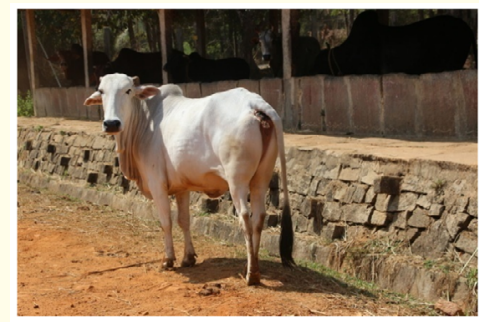

Figure 5

\section{Buffalo}

Most predominant buffalo breeds reared in Maharashtra are Nagpuri, Pandharpuri and Marathwadi.

Home tract of Nagpuri buffalo breed is Nagpur, Wardha, Akola, Amravathi and Yeotmal district of Maharastra, however distributed in Berar districts of Madhya Pradesh also. Population size is 1,27 000 as per ICAR - NBAGR (2000). Black in colour, sometimes there are white markings on the face, legs. Horns are flat-curved and carried back near to the shoulders. Body weight is $522 \mathrm{~kg}$. Lactation milk yield is $1040 \mathrm{~kg}$ in a period of 285 days. The age at first calving is $48 \mathrm{~m}$ with an inter-calving period of $17 \mathrm{~m}$.

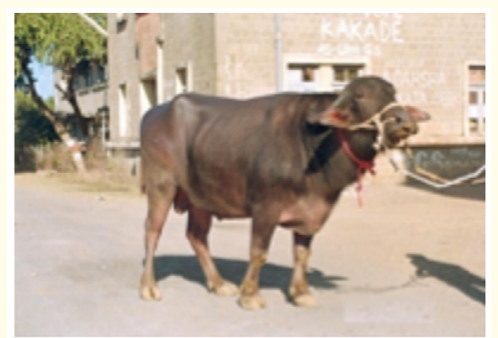

Figure 6

The name Pandharpuri is from the town Pandharpur in Solapur district which is the home tract of Pandharpuri buffalo. They are also found in Kolhapur and Sangli districts of Maharashtra. Popu- 
lation size is 2,60 000 as per ICAR - NBAGR (2000). The average body weight of 450 - $470 \mathrm{~kg}$. Typical characteristic of this breed is its horns which are very long, curved backward, upward and usually twisted outwards. The horns are very long extending beyond shoulder blade, sometimes up to pin bones. Under average management conditions and hot - dry climate these buffaloes yield 6 - $7 \mathrm{~kg}$ of milk per day. Lactation milk yield is $1800 \mathrm{~kg}$ in a period of 330 day.

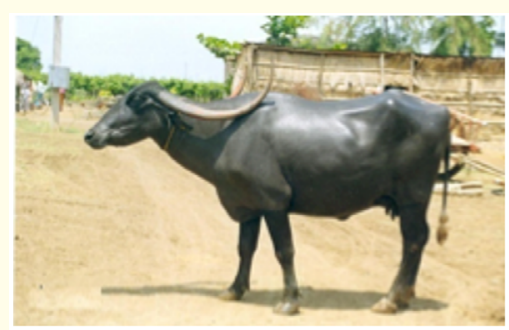

Figure 7

The breeding tract of Marathwadi buffalo breed includes Parbhani, Nanded, Beed, Jalna and Latur districts of Maharashtra. The breed is maintained for milk as well as draught/transport purposes. Population size is 1,81, 000 as per ICAR - NBAGR (2000). The animals are greyish black to jet black in colour and white markings are sometimes present on forehead and lower parts of the limbs. Horns are medium in length and parallel to the neck, reaching up to shoulder but never beyond shoulder blade like Pandharpuri breed. Average lactation milk yield is $1120 \mathrm{~kg}$ in a period of 300 days with average milk fat is $8.8 \%$.

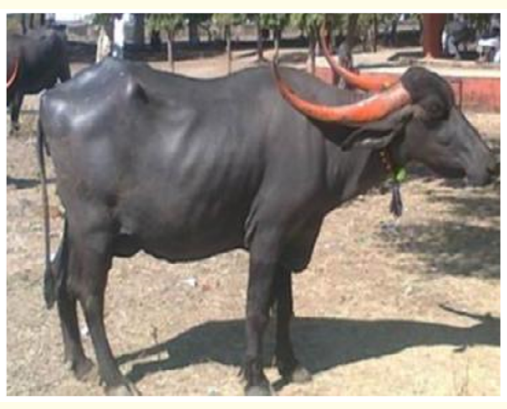

Figure 8
Goat

There are twenty six recognized breeds of goat in India, out of which four breeds namely Osmanabadi, Sangamneri, Berari and Konkan Kanyal are available in Maharashtra.

Osmanabadi goat breed is native to the Latur, Tuljapur and Udgir taluks of Osmanabad district of Maharashtra, from where they derive their name. They are also fairly widespread in Karnataka and Andhra Pradesh. According to the 18th Livestock Census 2007, the number of Osmanabadi goats in the country is $15,53,208$. The goats are large in size. The colour of the coat varies, but is mostly black (73\%), The breed is reared both for meat and milk production. Average daily milk yield $1.0 \mathrm{~kg}$ for a lactation length of about 4 months. The adult body weight in male and female is 35 and 30 $\mathrm{kg}$ respectively. They breed regularly twice a year and twinning is common.

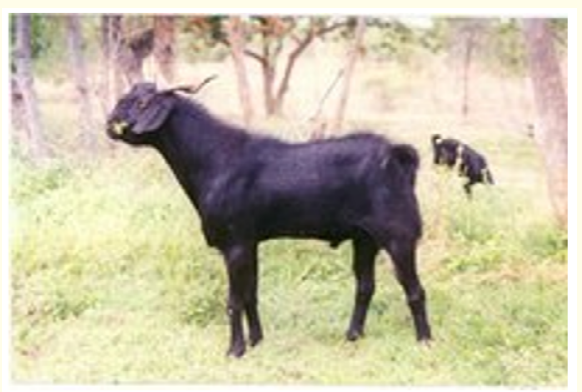

Figure 9

Sangamneri goat breed derives its name from the Sangamner Tehsil of Ahmednagar District. The semi arid region of Maharashtra comprising of Ahmednagar, Pune and Nasik districts forms the native habitat of this goat. According to the 18th Livestock Census 2007 , the number of Sangamneri goats in the country is 2,11,135. They are medium-sized animals. The coat colour is completely white with mixtures of black and brown. The litter size is mainly single, however 15 - 20\% goats show twinning. Although this breed is reared mainly for meat, some animals show a good milch potential. Average body weight in male and female is 40 and $32 \mathrm{~kg}$. Average milk yield is $120 \mathrm{~kg}$ in a lactation period of 150 days. This breed is available at MPKV, Rahuri. Maharashtra. 


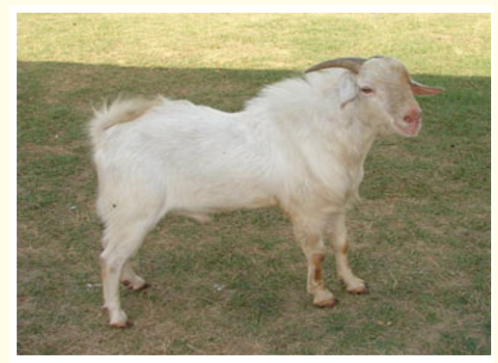

Figure 10

The Berari breed of goat is found in the Vidarbha region of Maharashtra. The breed is medium sized and primarily raised for meat production by local farmers. The population of this goat is estimated to be about $2,95,408$. The coat colour is light to dark tan. Berari goats have a black hair line along the vertebral column extending up to the tail. Average body weight in male and female is 38 and $28 \mathrm{~kg}$. Milk yield is about $43 \mathrm{~kg}$ in a lactation period of 120 days. These goats have good prolificacy, with the litter size ranging from single kids to four kids. Twinning is common.

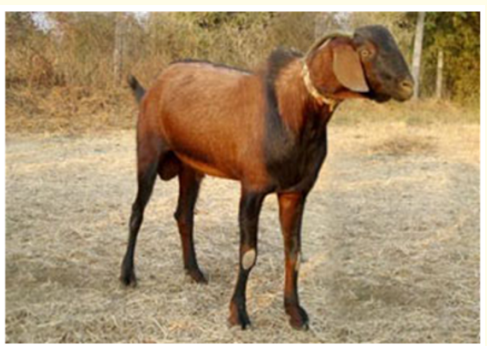

Figure 11

Konkan Kanyal goat is meat type breed adapted to high rainfall, hot and humid climate of Konkan region of Maharasthra. It was registered as a distinct breed by the NBAGR in May 2012. They are native to the Konkan region of Maharashtra and are reared for meat. These goats are mainly black with a white marking in a specific pattern. Animals have typical white bands on black face and black ear. The ventral surface of the body and the legs are white mostly. The body weight of adult bucks and does is 35 and $30 \mathrm{~kg}$ respectively. Konkan Kanyal goats are regular breeder and breed round the year, with a twinning percentage of about $66 \%$.

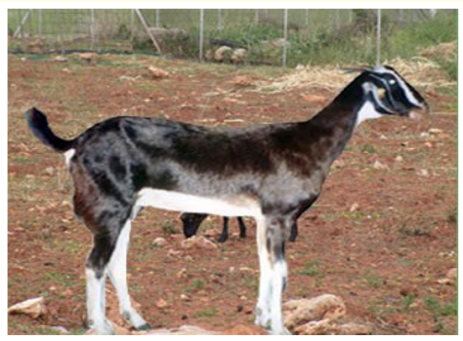

Figure 12

Sheep

The Deccani breed of sheep is widely distributed in the Deccan plateau across the two states of Maharashtra, Andhra Pradesh. It is also found in Karnataka and TN. The breed has a thin neck, narrow chest, prominent spinal processes. It has roman nose and dropping ears. The colour is dominantly black, with some grey and roan. Different strains (or within breed types) are observed in the breed tract. Four types have been noticed. Local people term them as Viz. Lonand, Sangamneri, Solapuri (Sangola) and Kolhapuri. This breed is reared for mutton purpose. Means of body weights at birth, three, six, nine and twelve months of age were 3.13, 14.30, 18.20, 20.10 and $22.57 \mathrm{Kg}$, respectively. Sheep were sheared two times a year. The average annual yield of wool being $4.54 \mathrm{~kg}$ per sheep. The wool is of a low grade and is a mixture of hair and fine fibres, mostly consumed for the manufacture of blankets. Deccani has the great potential for mutton production under intensive system of management.

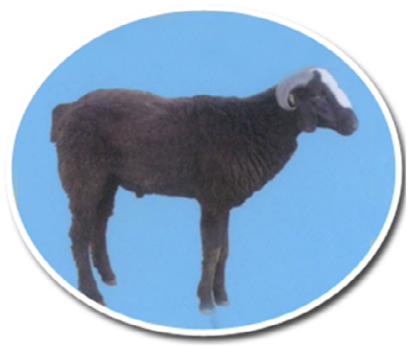

Figure 13 
Housing management of animal

- Presently main focus is on cow comfort, which will increase milk production and eliminate many animal health problems. So, design of house should be such that cow gets maximum comfort and least climatological stress to maximize production and increase income from dairy production.

- The most widely prevalent practice in the village is to tie the cow with rope on a katcha floor. Dairy cattle may be successfully housed under a wide variety of condition from close confinement to little restriction except at milking time. In Maharashtra cattle are maintained in stall-fed, semi intensive and loose housing system. Dairy cows in the village are kept in semi open RCC housing with concrete/brick floor and GI sheet/asbestos sheet/ corrugated iron sheet.

- In loose housing system animals are kept loose except milking and during treatment. It is very economical as cost of construction is lower than conventional type. In this system animals move freely in the paddock. Only during inclement weather, night time, milking and treatment cows are brought in the shed. So, animals get sufficient exercise for good health, production and reproduction.

- In conventional housing system separate cow shed, calving shed, calf shed, bull shed, store room and isolation shed for sick animals are constructed. This is comparatively costly due to more cost involvement in construction. But in this system cattle are more protected from adverse impact of climatic stress.

- Cowshed can be arranged in a single row if the number of cows are small, say less than 10 or in a double row if the number of head is large say 20 - 30. In double row housing stable should be so arranged so that the cows are placed either in face out ie tail to tail system or face in ie head to head system.

- Main advantage of tail to tail system is that cows get more fresh air from outside, lesser chance of spreading disease; wider middle alley is of great advantage during cleaning and milking the cows.

- In face to face system only advantage is that feeding of cows become easier.
Feeding and nutritional management of Animal:

- In general, feeding and management practices of livestock in Maharashtra is moderate. The region is deficient in production of cereals, pulses and vegetables, so also in livestock feed ingredients.

- Farmers are producing green fodder such as Guinea grass, Marvel grass, $\mathrm{CO}_{3}, \mathrm{CO}_{4}$ and few farmers are feeding crop residue available in their field i.e. jowar straw i.e. kadwa kutty, paddy straw as dry fodder. In draught affected area i.e. Marathawada region, sugarcane tops are being used as green fodder. Fodder production can be taken up at fallow lands, forest land to enhance milk production.

- $\quad$ Farmers are feeding pelleted feed directly to animals or sometimes they purchase feed ingredients from nearby market for preparing concentrate mash ration.

- In a study it was observed that $70.67 \%$ farmers use kadwa kutty and $20.18 \%$ farmers use paddy straw for feeding their livestock. However, 9.15\% farmers do not use any dry fodder for feeding their dairy animals. Regarding feeding of green fodder $45.6 \%$ farmers reported to use sugarcane tops, $26.7 \%$ feed maize, $21.5 \%$ feed hybrid napier such as $\mathrm{CO} 3, \mathrm{CO} 4$ etc. However, there is a good percent $(6.2 \%)$ of farmers who don't provide green fodder to their livestock due to scarcity. It was also reported that $66.6 \%$ farmers purchase pelleted feed to maintain high yielding dairy cattle and buffalo. $24.3 \%$ farmers prefer to purchase feed ingredients from local market and mix it to feed animals as mash form. However 9.1\% farmers don't provide any concentrate feed due to poor economic condition.

- Agro-industrial by-products namely rice polish, wheat bran, cottonseed cake are available. However, their digestibility is low. These products can be incorporated to some extent ie $10-15 \%$ in animal feed to reduce the feed cost, thereby reducing the cost of production.

- The breeding efficiency of a dairy herd cannot be maintained at a high level without proper nutrition. Cows in early lactation usually lose body weight until dry matter intake increases sufficiently to meet the nutrient demands of lactation.

- Excessive negative energy balance, as a result of poor feed intake in early lactation, is related to poor milk pro- 
duction, decreased reproductive performance and overall diminished herd health.

- Excessively fatty or thin cows are prone to metabolic disorder such as milk fever, ketosis which leads to poor conception rates i.e. repeat breeding and difficult calving i.e. dystocia and abortion.

- So, ration must be carefully balanced for protein, energy, minerals and vitamins to promote good reproductive perfor.

Disease incidence and health management of animal

- Most of the animals are suffering from worm infestation, enteritis, pyrexia, FMD, anorexia, debility, deficiency disorder, tympanitis, skin infection, eye infection, mastitis, agalactia, anoestrous, repeat breeding, metritis, retention of placenta, traumatic wound, patellar desmotomy, external growth, contagious ecthyma and abscess.

- Regular deworming is done at least twice a year. Regular immunization in cattle and buffalo against HS, BQ and FMD; and regular immunization in goat against PPR is done by State Animal Husbandry Deptt., Govt. of Maharashtra.

- Feedback of 344 veterinary officers of Maharashtra state was taken regarding the occurrence of infectious disease, systemic disease, reproductive disorders and constrains faced by them in controlling those diseases in different regions of Maharashtra in pre constructed format. It was revealed that PPR, Mastitis and Repeat breeding were most important infectious disease, systemic disease and reproductive disease respectively. Most important difficulty in controlling infectious diseases was found to be "Non cooperation from animal owners". The most important cause for difficulty in treatment of diseases was "High cost of treatment". It was also observed from the study that most important causes for reproductive problems at field level was "Nutritional deficiencies". Region wise analysis of data revealed that PPR was the most prevalent infectious disease in all the six regions of Maharashtra except in Pune. Mastitis was the most prevalent systemic disease in five regions ie Mumbai, Pune, Aurangabad, Latur and Amaravati. Repeat breeding was the predominant reproductive problem in all the seven regions of the state. Nutritional deficiency was found to be the main cause of reproductive problems [2].
Constrains and way forward

\section{Conservation of germplasam}

Conservation of indigenous elite germplasam in its own breeding tract is very important for full expression of genetic potentiality of those breeds of animal and maximum exploitation. Moreover indigenous animals are more heat tolerant and disease resistant. They produce less methane, so encouraging the farmers for rearing of indigenous animals is one of the best options of mitigation measure against climate impact.

Lack of quality feed and fodder

To get maximum potentiality of high yielding cattle and buffalo quality feed and fodder is very much needed. Moreover, nutrition of animal should be balanced with all nutrients as per production. In draught prone area of Maharashtra sugarcane tops are being fed as green fodder which causes drop of milk yield, poor health and leads to infertility problem due to mineral and vitamin deficiency. So, AH department has to take initiative for supplying draught resistant fodder seed and saplings to the livestock farmers of those area. In Maharashtra availability of fallow land is 25,70,000 hectare which can be utilized for production of fodder crops such as Barseem, Lucern, Stylo, Cow pea, Rice bean, Maize, Oat, Sorghum, Hybrid napier, Para grass, Guinea grass, Dasarath grass, Marvel grass etc. depending on soil quality, water availability and climatic condition etc. Even establishment of fodder bank may be implemented for easy availability of fodder seeds/saplings and demonstration purpose.

\section{Importance on climate resilient measures}

Animal housing and management is the high priority adaptation measure to minimize the effects of climate and climate change on livestock production. So climate resilient shed may be constructed at Govt. livestock farm for training and demonstration purpose of the different class of livestock stakeholders. Even subsidies may be given to farmers for constructing climate resilient shed for better production and management of animals.

Lack of medicine and vaccine in veterinary dispensary and hospital

All the animal health centers/dispensaries should ensure availability of most of the important medicines, particularly antibiotic, antipyretic, antihistaminic, anthelmentic, mineral and vitamin mixture and vaccine for the livestock owners for maintaining health and production of livestock. 
Lack of infrastructure in veterinary dispensary and hospital

It was observed that the building of Veterinary Dispensary and Hospital is in very poor shape, even furniture are very old, no facility of toilet etc. Minimum equipment facility are lacking for disease diagnosis, control and treatment of animals. So, necessary measure should be taken to upgrade the condition of Veterinary Dispensary and Hospital. Now a day's farmers are not interested to bring large animals to dispensary due to shortage of time, distance, poor condition of road etc. So, in this situation if facility for Mobile Veterinary Clinic is made all these problems would be solved.

\section{Lack of manpower in veterinary dispensary and hospital}

There is inadequate number of LDOs in certain areas as reflected by officers having the charge of 3 to 5 dispensaries/hospitals and had to cover more area and large number of animals, which may affect the service delivery. So, necessary step should be taken for filling up of vacant posts as early as possible to provide better veterinary service.

\section{Strengthening of linkage}

It is important for strengthening of linkage among State Agriculture Universities, State Veterinary Universities, ICAR institutes and State Departments. It is equally important to increase the linkage between the line departments in the state eg State Animal Husbandry, State Agriculture Department and State Fishery Departments for exchange of ideas and views for joint collaboration of organizing different capacity building programmes etc. for all round development of the state.

\section{Conclusion}

Maharashtra is rich source of livestock germplasam particularly in cattle, buffalo and goat. So, due care and attention is needed for veterinary services to keep the animals healthy and productive. Regular deworming and vaccination could reduce morbidity and mortality of the animals due to infectious diseases. There is immediate need for laboratory (serological and molecular) confirmation of clinically diagnosed cases for better confirmation of livestock diseases. The state animal husbandry departments should ensure availability of most of the important medicines and vaccine to the livestock owners for reducing the cost of treatment as well as maintaining health and production of livestock as it was observed that high cost of treatment and non - availability of medicine were major constrains faced by the field veterinarians. As nutritional de- ficiency is the major cause of reproductive disorder, so livestock owners should be well aware for the formulation of balanced nutrition at low cost for their livestock. Farmers should produce green fodder for feeding animals to reduce the reproductive diseases as far as possible. Moreover, timely checking of animal with qualified veterinary doctor is very essential to reduce different reproductive diseases as it was observed that improper timing of artificial insemination was second most important cause of reproductive disorder such as repeat breeding and infertility.

\section{Bibliography}

1. Anonymous. " $20^{\text {th }}$ Livestock Census. Department of Animal Husbandry and Dairying". Ministry of Fisheries, Animal Husbandry and Dairying. Govt. of India. New Delhi (2019).

2. Das S K., et al. "A Survey on the occurrence of livestock diseases and constrains in controlling those disease in Maharashtra". International Journal of Livestock Research 10.2 (2020): 89-96.

\section{Assets from publication with us}

- Prompt Acknowledgement after receiving the article

- Thorough Double blinded peer review

- Rapid Publication

- Issue of Publication Certificate

- High visibility of your Published work

Website: www.actascientific.com/

Submit Article: www.actascientific.com/submission.php

Email us: editor@actascientific.com

Contact us: +919182824667 